Copyright $@ 2010$ Institute of Electrical and electronics Engineers, Inc.

All Rights reserved.

Personal use of this material, including one hard copy reproduction, is permitted.

Permission to reprint, republish and/or distribute this material in whole or in part for any other purposes must be obtained from the IEEE.

For information on obtaining permission, send an e-mail message to stds-igr@ieee.org.

By choosing to view this document, you agree to all provisions of the copyright laws protecting it.

Individual documents posted on this site may carry slightly different copyright restrictions.

For specific document information, check the copyright notice at the beginning of each document. 


\section{Institutional, Economic and Technical Dimensions of Choosing Private Tertiary Education in Bangladesh: Lessons for Australian Universities}

\author{
Mohammad Salahuddin \\ Assistant Professor \\ Southeast University, \\ Dhaka \\ Bangladesh \\ E-mail: \\ salahuddin0000@yahoo.com
}

\author{
Delwar Akbar \\ Centre for Environmental \\ Management \\ Central Queensland \\ University \\ Rockhampton, Australia \\ E-mail: \\ d.akbar@cqu.edu.au
}

\author{
Obaidul Hamid \\ School of Languages and \\ Comparative Cultural \\ Studies \\ The University of \\ Queensland, Australia \\ E-mail: \\ obaid_hamid@yahoo.com
}

\author{
Rabiul Islam \\ PhD Student \\ Department of Economics \\ Monash University \\ Clayton, Australia \\ E-mail: \\ rabiul2001bd@yahoo.com
}

\begin{abstract}
Tertiary education in Bangladesh entered the private sector in the early 1990s. Fifty-four private universities are currently operating in the country. This paper examines the variables which determine students' choice of private universities for their tertiary studies in Bangladesh. The study involved 1000 respondents from eleven private universities. The sample allows for an empirical analysis of the variables that potentially influence students in choosing a particular private university. Factor analysis was used to group the variables into several dimensions or factors. The results show that institutional and economic factors such as quality education, job oriented subjects, physical environment and tuition fees were significant in influencing the choice variables, while technical factors such as advertisements, logistics and peer group influences were found to be less influential. Australian universities should look at institutional and economic factors in promoting their education overseas and attracting students from developing countries, especially from the South Asian countries.
\end{abstract}

Key words: Bangladesh, Private Tertiary Education, Choice Variables, Australian University

\section{INTRODUCTION}

Tertiary education has been available in Bangladesh since the first quarter of the last century. This education was introduced by the British colonial government through the establishment of the University of Dhaka in 1921 in response to popular demand for higher education in the region. Compared to this long history of tertiary education in the public sector, private sector university education was initiated in the 1990s. Specifically, the Private University Act of 1992 paved the way for the operation of private universities in Bangladesh. Although the Government at that time led by the Bangladesh Nationalist Party (BNP) was criticized, particularly by the intelligentsia, for entrusting the private sector with tertiary education, the growing popularity of the private tertiary education is attested by the fact that until 2005 54 private universities were operative in the country $[1,2]$. Moreover, the number of these universities is increasing day by day. Mainly, middle- and upper-class families can afford to send their children to these high fee-paying universities. Students from other social class backgrounds are unlikely to choose these universities mainly on the financial grounds. Since the existing 17 public universities can accommodate only $5 \%$ of the total higher education seeking student population, a significant number of students are denied access to higher education in the public sector. This wide gap between the demand of higher education and the capacity of the public universities has fuelled the popularity of private university education over the years. In addition, the demand for professional qualifications such as the Master of Information Technology (MIT) has increased over time because of growing business needs [3, 4]. Before the operation of private universities in Bangladesh, students from the middle class families went to India, Pakistan, Malaysia and Singapore, while upper class students went to the USA, Canada, Australia and UK for higher studies. After the establishment of private universities, more than two-thirds of these students now receive tertiary education in Bangladesh. Not only that, some students who lived in foreign countries with their parents have come back to Bangladesh to undertake tertiary education in private universities, especially in the fields of medicine and pharmacy. In addition, students from neighboring countries such as Nepal and Bhutan are also found studying in Bangladeshi private universities. Private universities have attracted a huge amount of investment from businessmen and benevolent educationists. These universities have employed a substantial skilled labor force. Thus the sector plays an important role in the economic and social development of the country.

The aim of this paper is to identify the choice variables that explain students' selection of a particular private university for tertiary study. The paper is organized as follows: section 2 presents a review of literature on the variables relating to choice of a private university; section 3 describes the data and the methodology; section 4 outlines the results and analysis and section 5 provides a conclusion. 


\section{CHOICE VARIABLES OF PRIVATE UNIVERSITIES IN BANGLADESH}

Research on higher education in Bangladesh, especially on the private university education, is very limited. This paper has examined most of the available journal and conference papers and books on this topic. There is a huge huge gap between the supply of and demand for tertiary education in the public sector, which drives students to seek private universities through their affordability in terms of tuition fees [5]. The credit transfer system with the foreign university and the market orientation subjects (such as business administration, information technology, computer science, engineering and medicine) and the Vice Chancellor's (VC) image as the key variables of students' choice of private universities [6]. Schofield [7] identified tuition fees as the main factor affecting a student's choice of a private university in Bangladesh. Mamun and Jesmine [8] identified teaching staff and learning support materials as the key variables in the choice of a private university. Mamun and Das [9] identified leadership of the university, especially the social and academic status of the Vice Chancellor (VC) and other senior officials (such as the Deans of different faculties) as the key factors which attract students to private universities. They also pointed out some other attracting factors, including library facilities, laboratory facilities and the scope for internship assistance for students.

Zahid et al. [10] undertook an extensive qualitative study of performance of business education in Bangladesh and identified the course system (year-end or semester-end examination), quality of teaching, medium of instruction, campus size and location, accommodation for students, campus facilities (such as auditorium, parking, canteen, indoor and outdoor parking facilities) as crucial factors in private university selection. Rahman [11] pointed out that fee structure, faculty strength and job security were the key considerations to students in choosing a private institution. $\mathrm{He}$ also identified the nature of the curriculum (i.e., discipline-based versus skilled-based program), the location and the outlook of the campus, and the number of full-time faculty members as important factors which attract students to private institutions. Majid et al. [12] had a similar focus and identified teaching quality, teaching learning methodology, teaching aids and support facilities as the basic selection criteria of business education in private institutions. Ahmed et al. [13] found that skill-based curriculum and teaching quality are the major considerations to students looking for private institutions for business study.

Middlehurst and Woodfield [14] emphasized that quality of education and education costs are factors attracting students to a private university. Quader et al. [15] provide an overall assessment of the performance of private universities in Bangladesh. They conclude that the quality of faculty members is the foremost consideration to students and their guardians in selecting a private university. They also identify the location of the institution and student accommodation as two other key selection factors. Recently, government approval has become one of the most important variables in the selection of a private university because most private universities commence their academic activities subject to government approval on the satisfaction of its terms and conditions over a period of time [16]. If a private university achieves government approval in due time, then this becomes one of the most important factors in attracting students. Gulshan and Paul [17] identified the recommendation of parents, the academic reputation of the institution and the availability of the desired program as the most important factors influencing students' choice of a private university. Thorton [18] showed that teaching quality was the most important factor in judging overall performance of tertiary education in Bangladesh.

From the above discussion it can be summarized that tuition fees (costs), market-oriented subjects, job prospects, leadership quality, quality of teaching and the number of fulltime faculty members, location, size and aesthetic appeal of the university, library, laboratory and recreation facilities, British versus American system of education and government approval are the key variables in attracting students to private universities in Bangladesh. To date, no study has been conducted in Bangladesh to identify statistically significant variables that students consider in choosing a private university. Hence this is the main contribution of this study. Furthermore, no study has as yet encompassed all possible variables that explain students' selection of private universities in Bangladesh.

\section{METHODOLOGY}

The variables identified above were taken to the primary stakeholders (i.e., students and teachers) for identifying major choice variables. Data were collected using a random sampling method. First, 11 of 54 private universities were selected on a subjective basis. These were North South University (NSU), American International University of Bangladesh (AIUB), Independent University, East West University, Stamford University, University of Development Alternative (UODA), Daffodil University, International Islamic University, Chittagong (IIUC), BRAC University, Asian University of Bangladesh (AUB) and Southeast University. The first nine universities were selected because these were rated 1 to 9 by University Grants Commission (UGC) of Bangladesh [19]. The last two universities were included because one of them (Asian University of Bangladesh) is the largest private university in Bangladesh in terms of student enrolment, while the other (Southeast University) is one of the fastest growing private universities in Bangladesh. A random sample of 100 students was drawn from each of the 11 universities. Data for 100 students were taken out as responses were incomplete. Thus, the final sample size for this study was 1000. The survey was undertaken in 2006. 
The dependent variable in this study was 'choice of private university' while the independent variables were: cost, location, image in the market, quality teaching, affiliation with foreign universities, credit transfer facilities with local and foreign universities, the Vice Chancellor's image, financial assistance (in various forms such as waiver of tuition fees, scholarships and course exemption), marketoriented curriculum, job placement opportunity, advertisement, logistics, presence of a disciplined environment, convenience of mode of payment and influence of peer groups.

One limitation of the study lies in the selection of the private universities on the basis of convenience sampling. Therefore the findings may not represent all private universities. However, the sample represents represent the majority of the universities, since $60 \%$ of the total students studying in private universities in Bangladesh were enrolled in these 11 universities. The second limitation of the study is that it uses a dichotomous scale (see responses in Table A-1) to operationalize the variables. This was due to the level of patience that students were considered to demonstrate in completing the questionnaire.

Factor analysis was used to group the variables into different dimensions of pedagogical standard or factors. The measurement model used for scale development in structural covariance analyses consists of a set of $(p)$ regression equations linking the $(p)$ measured $(y)$ variables with $(m)$ scales or factors (latent variables $\eta$ ). If both the response variables and the latent factors are normally distributed with zero means and unit variances, this leads to the following system of equations written as follows using standard terminology [20]:

$y_{1}=\varphi_{11} \eta_{1}+\varphi_{12} \eta_{2}+---+\varphi_{1 m} \eta_{m}+\varepsilon_{1}-----(i)$ $y_{2}=\varphi_{21} \eta_{2}+\varphi_{22} \eta_{2}+---+\varphi_{2 m} \eta_{m}+\varepsilon_{2}--(i i)$ $y_{p}=\varphi_{p 1} \eta_{1}+\varphi_{p 2} \eta_{2}+---+\varphi_{p m} \eta_{m}+\varepsilon_{p}---($ iii $)$ Or, using matrix notation: $y=\Gamma \eta+\mathcal{E}--\frac{p}{p m}-(i v)$

Where, $y$ is a (p x 1) vector of observed variables, $\Gamma$ is a (p x m) matrix of factor loadings and $\eta$ is a ( $\mathrm{mx} 1)$ vector of scales (latent variables or factors), and $\mathcal{E}$ is a (p x 1) vector of error terms. The following section provides a discussion of the results of the factor analysis.

\section{FINDINGS AND ANALYSIS}

This section analyses the survey findings on variables influencing students' choice of private universities in Bangladesh.

Table-A1 shows the Pearson correlation matrix with 15 variables reported by the entire sample of 1000 students. The correlation matrix displays the pattern of relationships between the variables considered as the potential factors influencing student's choice of private universities. Correlation analysis demonstrates that the independent variables were positively correlated with one another at $99 \%$ confidence interval. Usually variables displaying very low correlations (less than 0.30) and very high correlations (greater than 0.90) are removed in order to avoid statistical problems (multicollinearity in the latter case). It is evident in this study that the range of correlations $(0.302$ to 0.78$)$ is within a reasonable limit and there was no need to eliminate any of the independent variables. The most commonly used indicator of internal consistency is Cronbach's alpha coefficient. Ideally, this should be above 0.7 [21]. In this study, the variables affecting the choice of private universities have strong internal consistency, with a Cronbach's alpha coefficient estimated at 0.9262 .

Table-A2 describes the extraction method. It is known that there will be as many eigenvectors as there are variables. Using Kaiser's criterion, only those factors which have eigenvalues of 1 or more were considered. Eigenvalues represent total variance explained by each factor. Table 2 shows that the first three factors (factors 1,2 and 3) meet this criterion explaining 75.417 percent of the total variance shown in the cumulative percentage column.

Table 1 presents the main contribution of this study. It describes the rotation of the three factors identified as important through extraction method and these are categorized as economic, institutional and technical, although they are some overlaps among the factors. Among the several methods available in factor analysis to extract factors, the method adopted here is Principal Component Analysis followed by Varimax rotation with Kaiser normalization.

Before rotation all variables were loaded highly on the first factor and the remaining factors did not have any loading. However, the rotation of the factor structure clarified the interpretation of each of the three extracted factors shown in Table 1. Variables with a factor loading of higher than 0.70 are grouped under that factor. The main loadings on Factor 1 (mainly economic along with some other's overlapping) are the variables of cost, convenient mode of payment, location and image of the VC. The variables relating to Factor 2 (mainly institutional along with some overlap) are quality of teaching, disciplined environment, image in the market and market orientation of the course curriculum. Finally, the main items of Factor 3 (mainly technical along with some overlap) are job placement opportunities and affiliation with foreign universities.

Table 1: Rotated component matrix

\begin{tabular}{|c|c|c|c|}
\hline \multirow{2}{*}{} & \multicolumn{3}{|c|}{ Component } \\
\cline { 2 - 4 } & 1 & 2 & 3 \\
\hline Cost & .853 & & \\
\hline Payment & .821 & & \\
\hline Location & .799 & & \\
\hline VC & .708 & & \\
\hline Finance & .604 & & \\
\hline Quality & & .844 & \\
\hline
\end{tabular}




\begin{tabular}{|c|l|l|l|}
\hline Environment & & .831 & \\
\hline Image & & .755 & \\
\hline Curriculum & & .730 & \\
\hline Job & & & .770 \\
\hline Affiliation & & & .755 \\
\hline Credit transfer & & & .682 \\
\hline Peer group & & & .660 \\
\hline Advertisement & & & .633 \\
\hline Logistic & & & .607 \\
\hline
\end{tabular}

Source: Salahuddin et al. [22]

The above findings indicate that variables such as cost, mode of payment, quality of teaching and the environment have been found to significantly influence students' choices of private universities for tertiary education. The findings are relevant to the level of the economic development of Bangladesh as well as to people's motivation for higher education. It is obvious that students consider cost and costrelated factors more than anything else because a significant number of students come from middle-class families. In other words, these families have to make a lot of sacrifice to support their children's university education with a view to preparing them for the future job market. The fact that the quality of teaching has been found to be a very significant factor in influencing students is also an expected outcome of this research. Factors such as advertisement (publicity) and the image of $\mathrm{VC}$ have been shown to be less important in attracting students to these private sector institutions.

\section{CONCLUSIONS AND LESSONS FOR AUSTRLIAN UNIVERSITIES}

This study concludes that students consider cost, convenient mode of payment, quality of teaching and the campus environment as the most important factors when deciding where they will pursue their tertiary education. Cost is the most significant factor, since the vast majority of students seeking admission to private universities in Bangladesh come from middle-class backgrounds. However, because of high fee structure, private university education is still not accessible to many students.

Choosing private universities in Bangladesh and universities in Australia provides two different contexts to Bangladeshi higher education seekers. However, research on international students in Australian universities shows that the variables influencing their choice of Australian institutions or their levels of satisfaction are not entirely dissimilar. For instance, Forbes-Mewett et al. [23] show that income security, by which they mean the sources of international student income, the extent to which international students experience income security/insecurity, how they cope with income difficulties, and how they ensure that finance does not become a serious problem, is the manifest consideration of international students in Australian universities. Similarly, Pimpa [24] shows that to Thai students in Australia, finance was a major consideration together with availability of information, education expectations and persuasion. Arambewela [25] worked with Chinese, Indian, Indonesian and Thai students in Australian universities. His research found that education standards and facilities, customer value and study outcomes and institutional image, prestige and recognition were the most dominant factors influencing the post-choice satisfaction of these students. More recently, Brown [26] found that institutional image was the key consideration in the selection of higher education institution in Australia.

Given this broad similarity in the choice variables, the findings of the current study have implications for Australian universities seeking students from Bangladesh and its surrounding region. These universities should understand that higher education seekers in this region are motivated by economic and institutional factors in selecting options for tertiary education. While economic considerations drive Australian universities to open themselves to overseas students, there should be some provision to ensure that prospective students from this region do not find the cost of Australian education exorbitantly expensive, or that there is income security for these students, as argued by ForbesMewett et al. [27]. In addition, Australian universities should maintain the quality of education in order to attract students from developing countries.

\section{ACKNOWLEDGEMENT}

This paper is based on Salahuddin et al. (see reference 22). Permission was obtained from the project leader (Mr. Salahuddin) for using their project output and literature.

\section{REFERENCES}

[1] Gulshan, J. and Paul, A. (2005) Factors influencing students choosing private universities in Banadesh, Paper presented at the ISCM Conference 2005, Eastin Hotel, Petaling Jaya, Malaysia, 27-31 December.

[2] Quader, M. S., Shahidullah, M. and Sultana R. A. (2005) The Private Universities of Bangladesh: An Assessment, University of Science and Technology Annual, 11, pp. 117-123.

[3] Hopper, R. (1996), The new universities of Bangladesh: a case study in private postsecondary education, International Educator, 7, pp. 36-38.

[4] Hopper, R. (1998), Emerging Private Universities of Bangladesh: Public Enemy or Ally? International Higher Education (Winter, 1998).

[5] Hopper, R. (1996), The new universities of Bangladesh: a case study in private postsecondary education, International Educator, 7, pp. 36-38.

[6] Hopper, R. (1998), Emerging Private Universities of Bangladesh: Public Enemy or Ally? International Higher Education (Winter, 1998). Internet

[7] Schofield, A. (1996) Private Post-Secondary Education in Four Commonwealth Countries, Paris, UNESCO.

[8] Mamun, M. Z. and Jesmin, R. (1999) Quality functions deployment of the non-government universities of Bangladesh, Journal of Business Administration , 25, pp. 21-41.

[9] Mamun, M. Z. and Das, S. (1999) Total Quality Management for NonGovernment Universities of Bangladesh, Proceedings of Annual Convention of Bangladesh Society for Total Quality Management in Association with Department of Industrial and Production Engineering, BUET, Dhaka, December 3-4, 1999, pp. 23-29.

[10] Zahid, J. R., Chowdhury G. M. and Sogra . J. (2000), Present Status and Future Direction of Business Education in Bangladesh, Journal of Business Administration, 26, pp. 11-24.

[11] Rahman, N. (2000), Business education in Bangladesh: developing a need-based perspective, Journal of Business Administration, 26, pp. 110. 
[12] Majid A. K. M. S., Mamun, M. Z. And Siddique, S. R. (2000), Practices of Teaching Methods, Aids and Students' Performance Evaluation Tools in Business Schools of Bangladesh: Selected Cases, Journal of Business Administration, 26, pp. 25-45.

[13] Ahmed, M. Ahmed, M. and Anwar, S. F. (2000) Bridging the Gap Between Expectations of the Business Community and Delivery of the Business Schools in Bangladesh, Journal of Business Administration, 26, pp. 47-66.

[14] Middlehurst, R. and Woodfield, S. (2004) The Role of Transnational, Private, and For-Profit Provision in Meeting Global Demand for Tertiary Education: Mapping, Regulation and Impact, Vancouver, Commonwealth of Learning and UNESCO.

[15] Quader, M. S., Shahidullah, M. and Sultana R. A. (2005) The Private Universities of Bangladesh: An Assessment, University of Science and Technology Annual, 11, pp. 117-123.

[16] Chowdhury, A. I. (2001) Private Universities in Bangladesh: Governance, Quality of Education and Expectations, Proceedings of the Seminar, Dhaka, University Grants Commission of Bangladesh.

[17] Gulshan, J. and Paul, A. (2005) Factors influencing students choosing private universities in Bangladesh, Paper presented at the ISCM Conference 2005, Eastin Hotel, Petaling Jaya, Malaysia, 27-31 December.

[18] Thornton, H. (2006), Teachers talking: the role of collaboration in secondary schools in Bangladesh, Compare, 36, pp.181-196.

[19] The Daily Star Reporter (2004) University Grant Commission report on the performance of private universities in Bangladesh, The Daily Star, Dhaka, 18 October, 2004.

[20] Jöreskog K. G. (2001), Factor Analysis of Ordinal Variables: A Comparison of Three Approaches, Multivariate Behavioral Research, 36, pp. 347-387.

[21] Pallant, J (2000) Development and validation of a scale to measure perceived control of internal states, Journal of Personality Assessment, 75, pp. 308-337.

[22] Salahuddin, M., Islam, R. and Raihan, K.M. (2006), Factors Affecting Students' Choice of Private University in Bangladesh, "Unpublished Research Project", Southeast University, Dhaka.

[23] Forbes-Mewett, H., Chung, M., Marginson, S., Nyland, C., Ramia, G. \& Sawir, E. (2006). Income security of international students in Australia. ISANA, The Gap, Queensland.

[24] Pimpa, N. (2002). Marketing of international education: the influence of normative referents on Thai students' choices of international education. "Unpublished PhD Thesis". Monash University, Victoria, Australia.

[25] Arambewela, R. A. (2003). Post-choice satisfaction of international postgraduate students from Asia studying in Victorian universities. "Unpublished $\mathrm{PhD}$ Thesis", Victoria University of Technology, Victoria, Australia.

[26] Brown, R. M. (2007). Drivers of student satisfaction and student loyalty in an Australian university setting. "Unpublished $\mathrm{PhD}$ Thesis", University of Western Australia, Perth, Australia.

[27] Forbes-Mewett, H., Chung, M., Marginson, S., Nyland, C., Ramia, G. \& Sawir, E. (2006). Income security of international students in Australia. ISANA, The Gap, Queensland. 


\section{APPENDICES}

Table A1: Correlation among the variables relevant to selection private universities

\begin{tabular}{|c|c|c|c|c|c|c|c|c|c|c|c|c|c|c|c|}
\hline & Cost & Loc & Image & Qlt & Aff & Crdt & VC & Fnc & Cur & Job & Adv & Lgst & Env & Pay & PGI \\
\hline Cost & 1 & & & & & & & & & & & & & & \\
\hline Loc. & 0.69 & 1 & & & & & & & & & & & & & \\
\hline Image & 0.41 & 0.45 & 1 & & & & & & & & & & & & \\
\hline Qlt. & 0.34 & 0.46 & 0.67 & 1 & & & & & & & & & & & \\
\hline Aff. & 0.37 & 0.51 & 0.58 & 0.48 & 1 & & & & & & & & & & \\
\hline Crdt. & 0.45 & 0.58 & 0.64 & 0.50 & 0.83 & 1 & & & & & & & & & \\
\hline VC & 0.61 & 0.77 & 0.46 & 0.40 & 0.47 & 0.57 & 1 & & & & & & & & \\
\hline Fnc. & 0.61 & 0.72 & 0.64 & 0.55 & 0.54 & 0.67 & 0.67 & 1 & & & & & & & \\
\hline Cur. & 0.50 & 0.62 & 0.63 & 0.66 & 0.58 & 0.62 & 0.54 & 0.69 & 1 & & & & & & \\
\hline Job & 0.33 & 0.5 & 0.62 & 0.44 & 0.72 & 0.72 & 0.58 & 0.55 & 0.5 & 1 & & & & & \\
\hline Adv. & 0.51 & 0.48 & 0.34 & 0.24 & 0.48 & 0.46 & 0.45 & 0.4 & 0.32 & 0.48 & 1 & & & & \\
\hline Lgst. & 0.57 & 0.64 & 0.59 & 0.41 & 0.66 & 0.65 & 0.64 & 0.67 & 0.56 & 0.60 & 0.58 & 1 & & & \\
\hline Env & 0.41 & 0.49 & 0.75 & 0.72 & 0.55 & 0.62 & 0.43 & 0.67 & 0.72 & 0.56 & 0.32 & 0.55 & 1 & & \\
\hline Pay & 0.78 & 0.78 & 0.48 & 0.40 & 0.52 & 0.61 & 0.69 & 0.7 & 0.59 & 0.43 & 0.49 & 0.66 & 0.49 & 1 & \\
\hline PGI & 0.53 & 0.54 & 0.44 & 0.30 & 0.53 & 0.58 & 0.52 & 0.51 & 0.41 & 0.57 & 0.50 & 0.65 & 0.41 & 0.52 & 1 \\
\hline
\end{tabular}

Note: Loc.= Location, Qlt.= Quality, Aff.= Affiliation, Cur.= Curriculum, Adv.= Advertisement, Lgst.= Logistic, Env.= Environment, Pay = Payment, PGI = Peer group influence. Source: Salahuddin et al. [see reference 22]

Table A2: Total variance explained by factors

\begin{tabular}{|c|c|c|c|c|c|c|c|c|c|}
\hline \multirow[b]{2}{*}{ Variable } & \multicolumn{3}{|c|}{ Initial Eigenvalues } & \multicolumn{3}{|c|}{$\begin{array}{c}\text { Extraction Sums of Squared } \\
\text { Loadings }\end{array}$} & \multicolumn{3}{|c|}{ Rotation Sums of Squared Loadings } \\
\hline & Total & $\begin{array}{c}\% \text { of } \\
\text { Variance }\end{array}$ & $\begin{array}{c}\text { Cumulative } \\
\%\end{array}$ & Total & $\begin{array}{c}\% \text { of } \\
\text { Variance }\end{array}$ & $\begin{array}{c}\text { Cumulative } \\
\%\end{array}$ & Total & $\begin{array}{c}\% \text { of } \\
\text { Variance }\end{array}$ & $\begin{array}{c}\text { Cumulative } \\
\%\end{array}$ \\
\hline 1 & 8.745 & 58.297 & 58.297 & 8.745 & 58.297 & 58.297 & 4.001 & 26.676 & 26.676 \\
\hline 2 & 1.473 & 9.820 & 68.117 & 1.473 & 9.820 & 68.117 & 3.811 & 25.405 & 52.081 \\
\hline 3 & 1.095 & 7.299 & 75.417 & 1.095 & 7.299 & 75.417 & 3.500 & 23.336 & 75.417 \\
\hline 4 & 0.602 & 4.016 & 79.433 & & & & & & \\
\hline 5 & 0.490 & 3.268 & 82.701 & & & & & & \\
\hline 6 & 0.462 & 3.078 & 85.779 & & & & & & \\
\hline 7 & 0.382 & 2.550 & 88.329 & & & & & & \\
\hline 8 & 0.339 & 2.262 & 90.591 & & & & & & \\
\hline 9 & 0.295 & 1.969 & 92.560 & & & & & & \\
\hline 10 & 0.259 & 1.726 & 94.285 & & & & & & \\
\hline 11 & 0.207 & 1.379 & 95.665 & & & & & & \\
\hline 12 & 0.192 & 1.277 & 96.942 & & & & & & \\
\hline 13 & 0.181 & 1.209 & 98.150 & & & & & & \\
\hline 14 & 0.155 & 1.036 & 99.186 & & & & & & \\
\hline 15 & 0.122 & 0.814 & 100.000 & & & & & & \\
\hline
\end{tabular}

Note: extraction method: Principal Component Analysis; Source: Salahuddin et al. [see reference 22] 